\title{
KAJIAN IMPLEMENTASI PERATURAN MENTERI PERDAGANGAN NOMOR 57 TAHUN 2017 DI BANDAR LAMPUNG
}

\author{
(Study on implementation of Minister of Trade Regulation Number 57 of 2017 in Bandar Lampung)
}

Febrina Veronika Saragih, Zainal Abidin, Ktut Murniati

Jurusan Agribisnis, Fakultas Pertanian, Universitas Lampung, Jl. Prof. Dr. Soemantri Brodjonegoro No. 1 Bandar Lampung 35145, Telp. 082370649476, e-mail: vsfebrina@gmail.com

\begin{abstract}
This research was conducted to find out the implementation of Minister of Trade regulation number 57 of 2017 in Bandar Lampung and to determine its supporting and inhibiting factors. This study used a qualitative descriptive method and the research location was chosen purposively with the consideration that Bandar Lampung is an area with high population, economic center, and high consumtion of rice as staple food. The sample size was 25 people consisting of 4 farmers, 2 huller entrepreneurs, 2 large traders, 4 retailers, 12 rice consumers and 1 person as a representative of the food task force. Data collection was conducted in February 2018. The data analysis method used was qualitative descriptive to determine the performance and using Ripley and Franklin's theory to find out the supporting and inhibiting factors. The results showed that the implementation of Minister of Trade regulation number 57 of 2017 in Bandar Lampung was ineffective, although it has supporting factors such as the existence of Standard Operating Procedures (SOP) from the regulations and the establishment of a food task force. Inhibiting factors are the ineffectiveness of the existing food task force, noncompliance of rice business actors, lack of information about policies at the level of rice business actors and the contents of regulations that are not in accordance with the needs of rice business actors.
\end{abstract}

Key words: implementation, regulation, rice, trade

\section{PENDAHULUAN}

Indonesia merupakan negara agraris yang sebagian besar penduduknya hidup dengan mata pencaharian sebagai seorang petani. Hingga kini masyarakat Indonesia masih memanfaatkan sumber daya alam dan bergantung pada sektor pertanian untuk mempertahankan hidupnya. Sektor pertanian memiliki fungsi yang sangat penting sebagai penghasil pangan bagi masyarakat Indonesia yang jumlahnya semakin bertambah.

Peningkatan jumlah penduduk menyebabkan terjadinya konversi lahan sawah menjadi pemukiman sehingga jumlah produksi pangan menurun. Banyaknya konversi lahan sawah diperkirakan akan mengancam kesinambungan produksi beras nasional yang dapat menyebabkan ketergantungan terhadap beras impor (Kulsum, Arifin, dan Abidin 2015).

Fenomena El Nino juga mempengaruhi penurunan produksi pangan, El Nino akan mengakibatkan perubahan pola iklim tahunan seperti terlambatnya awal musim hujan maupun musim kering. Adanya gangguan El Nino mengakibatkan berkurangnya ketersediaan air (Nopralita, Abidin, dan Affandi 2017).

Pada kenyataannya predikat negara agraris belum mampu membuat Indonesia mencapai ketahanan pangan. Hal ini dibuktikan dengan kegiatan impor pangan yang masih dilakukan Indonesia. Pangan yang paling banyak diimpor oleh Indonesia adalah beras sebesar 2 juta ton pertahun (Kementrian Pertanian 2016).

Bandar Lampung termasuk wilayah dengan jumlah penduduk yang cukup besar yaitu 1,6 juta jiwa. Masyarakat yang tinggal di Ibukota cenderung modern dimana makanan pokoknya adalah beras. Hal ini ditunjukkan melalui data yang dikeluarkan oleh Badan Pusat Statistik (2017) dimana masyarakat Bandar Lampung mengeluarkan 10,25 persen dari total pendapatannya untuk membeli padi-padian berupa beras. Jumlah ini cukup besar bila dibandingkan persentase pengeluaran menurut kelompok makanan lainnya seperti daging, ikan, aneka sayur dan buah.

Kenaikan harga suatu barang dapat menyebabkan inflasi pada suatu wilayah atau negara. Inflasi adalah kecenderungan dari kenaikan harga-harga 
pada umumnya serta terjadi secara terus-menerus (Waluyo 2002).

Harga yang tidak stabil serta seringnya terjadi inflasi sehingga mendorong pemerintah untuk mengeluarkan peraturan Harga Eceran Tertinggi. Peraturan Harga Eceran Tertinggi dimuat dalam Peraturan Menteri Perdagangan No.47 Tahun 2017 yang disahkan pada 18 Juli 2017. Peraturan ini dibuat untuk mencapai stabilitas harga beberapa komoditas dan mencegah pedagang bermain dengan harga serta mengurangi kerugian yang dialami konsumen akibat harga yang ditetapkan terlalu tinggi, namun peraturan ini tidak maksimal sehingga dicabut kembali. Setelah peraturan ini dibentuklah peraturan menteri perdagangan No. 57 tahun 2017 yang disahkan pada 24 Agustus 2017 untuk menyempurnakan peraturan sebelumnya. Peraturan menteri perdagangan No. 57 ini hanya berisi Harga Eceran Tertinggi beras.

Berdasarkan uraian latar belakang, maka penelitian ini bertujuan mengetahui Implementasi Peraturan Menteri Perdagangan No.57 Tahun 2017 di Bandar Lampung tentang harga eceran tertinggi beras pada pedagang beras dan mengetahui faktor pendukung dan penghambat Implementasi Peraturan Menteri Perdagangan No. 57 Tahun 2017 di Bandar Lampung.

\section{METODE PENELITIAN}

Metode dasar penelitian ini adalah metode survei yaitu metode pengumpulan data primer dengan memberikan pertanyaan-pertanyaan kepada responden individu, sehingga dapat disimpulkan survei adalah metode untuk mengumpulkan informasi dari kelompok yang mewakili sebuah populasi yaitu sejumlah besar responden (Surakhmad 1994).

Penentuan lokasi penelitian dilakukan secara sengaja (purposive) dengan pertimbangan bahwa Bandar Lampung merupakan suatu wilayah dimana jumlah penduduknya cukup tinggi dan mengonsumsi beras sebagai makanan pokoknya, Ibukota provinsi, berdekatan dengan Jakarta sebagai Ibu Kota negara dan rentan terhadap kegiatan impor karena memiliki dua buah pelabuhan. Pengambilan sampel menggunakan teknik non probability sampling yaitu teknik sampling yang tidak memberikan kesempatan yang sama kepada setiap anggota populasi untuk dijadikan anggota sampel, sehingga penelitian ini menggunakan teknik snowball sampling.
Sugiyono (2001) mengatakan snowball sampling adalah teknik penentuan sampel yang mula-mula jumlahnya kecil, kemudian sampel ini disuruh memilih teman-temannya untuk dijadikan sampel begitu seterusnya, sehingga jumlah sampel semakin banyak. Ibarat bola salju yang menggelinding semakin lama semakin besar. Responden pertama merupakan pedagang besar yang nantinya akan memberikan informasi mengenai sampel berikutnya. Responden terdiri dari 4 orang petani, 2 pemilik huller, 2 orang pedagang besar, 4 orang pedagang pengecer, 12 orang konsumen beras dan 1 orang mewakili satgas pangan.

Data yang dikumpulkan terdiri dari data primer dan data sekunder. Data primer yang diperoleh yaitu berupa identitas responden, harga gabah dan beras, sedangkan data sekunder berupa data inflasi, data kandungan gizi beras, harga beras dan sebagainya. Metode analisis data yang digunakan adalah metode analisis kualitatif.

Metode analisis untuk menjawab tujuan kedua yaitu untuk mengetahui faktor pendukung dan penghambat implementasi peraturan menggunakan teori Ripley dan Franklin. Teori ini menekankan pada usaha untuk mengidentifikasi faktor-faktor apa saja yang mempengaruhi suatu kebijakan dapat berjalan sukses dilapangan. Teori ini terdiri dari tiga cara dominan yang sangat mempengaruhi keberhasilan implementasi kebijakan yaitu : (1) tingkat kepatuhan pada ketentuan yang berlaku, pada aspek ini dilihat melalui tingkat kepatuhan responden petani, pedagang besar hingga pengecer terhadap peraturan menteri perdagangan No. 57 tahun 2017 yang berisi harga eceran tertinggi beras beserta beberapa penyebab ketidakpatuhan tersebut; (2) lancarnya pelaksanaan rutinitas fungsi, pada aspek ini dilihat melalui kendala dari pelaksanaan peraturan, seperti kurangnya informasi yang didapat responden, isi peraturan yang ditetapkan tidak sesuai dengan yang dibutuhkan, serta dilihat frekuensi penerapan peraturan oleh responden; (3) terwujudnya kinerja dan dampak yang dikehendaki, pada aspek ini dilihat melalui penerapan peraturan oleh responden, tujuan yang diharapkan dari penerapan peraturan menteri perdagangan No. 57 tahun 2017 (Fatih 2010). 


\section{HASIL DAN PEMBAHASAN}

\section{Karakteristik Responden}

Usia rata-rata petani adalah 43,5 tahun dengan jenis kelamin semuanya laki-laki. Seluruh petani bertempat tinggal di Natar. Responden pemilik huller keduanya berjenis kelamin laki-laki dengan usia rata-rata 47,5 tahun. Lokasi operasi huller keduanya beralamat di Natar. Usia rata-rata pedagang besar adalah 61 tahun, masing-masing beralamat di Tanjung Karang dan Pasar Tugu. Usia rata-rata pedagang pengecer berkisar 60,5 tahun. Rata-rata usia konsumen pada penelitian adalah 41,67 tahun.

\section{Harga Gabah}

Kualitas gabah dan masa panen mempengaruhi harga jual gabah. Pada saat musim panen harga gabah cenderung rendah karena melimpahnya hasil panen, sedangkan saat musim paceklik atau bukan musim panen maka harga gabah akan meningkat.

\section{Harga gabah di tingkat petani}

Gabah yang dijual oleh petani berupa gabah kering panen. Petani melakukan usahatani padi di lahan milik sendiri. Sarana produksi yang digunakan oleh petani seperti cangkul, ember, sabit, mesin penyemprot dan faktor produksi seperti bibit, pupuk, obat hama dan penyakit dan lainnya. Pada penelitian ini ditemukan rata-rata harga jual gabah pada petani yaitu Rp 4.275/kg pada kondisi sedang panen raya. Rata-rata jumlah penjualan gabah sebesar 14 ton. Harga gabah di tingkat petani dapat dilihat pada Tabel 1 .

\section{Harga gabah dan beras di tingkat huller}

Huller merupakan mesin yang digunakan untuk mengolah gabah menjadi beras. Pemilik huller berperan sebagai tengkulak, distributor atau pedagang besar. Harga gabah dan beras di tingkat huller dapat dilihat pada Tabel 2.

Tabel 1. Harga gabah di tingkat petani pada Februari 2018 di Bandar Lampung

\begin{tabular}{ccc}
\hline $\begin{array}{c}\text { Nomor } \\
\text { responden }\end{array}$ & $\begin{array}{c}\text { Harga gabah } \\
(\mathrm{Rp} / \mathrm{kg})\end{array}$ & $\begin{array}{c}\text { Rata-rata } \\
\text { penjualan } \\
\text { (ton) }\end{array}$ \\
\hline 1. & 4.300 & 7 \\
2. & 4.300 & 15 \\
3. & 4.200 & 25 \\
4. & 4.300 & 9 \\
\hline Rata-rata & 4.275 & 14 \\
\hline
\end{tabular}

Tabel 2. Harga gabah dan beras di tingkat Huller pada Februari 2018 di Bandar Lampung

\begin{tabular}{|c|c|c|c|c|}
\hline No & $\begin{array}{l}\text { Asal } \\
\text { gabah }\end{array}$ & $\begin{array}{c}\text { Harga } \\
\text { beli gabah } \\
(\mathrm{Rp} / \mathrm{kg})\end{array}$ & $\begin{array}{l}\text { Jumlah } \\
\text { pembelian } \\
\text { (ton) }\end{array}$ & $\begin{array}{c}\text { Harga jual } \\
\text { beras } \\
(\mathrm{Rp} / \mathrm{kg})\end{array}$ \\
\hline 1. & $\begin{array}{l}\text { Metro } \\
\text { dan } \\
\text { Natar }\end{array}$ & 4.700 & 20 & 11.000 \\
\hline 2. & Natar & 4.300 & 2 & 11.500 \\
\hline \multicolumn{2}{|c|}{ Rata-rata } & 4.500 & 11 & 11.250 \\
\hline
\end{tabular}

Tabel 2 menunjukkan huller membeli gabah pada petani dengan rata-rata harga $\mathrm{Rp} 4.500 / \mathrm{kg}$ dan harga jual dalam bentuk beras sebesar Rp $11.250 / \mathrm{kg}$. Setiap pemilik huller memiliki kapasitas beli gabah dan kapasitas jual beras yang berbeda tergantung kapasitas mesin yang dimiliki, tenaga kerja dan jumlah pasokkan gabah. Rata-rata jumlah pembelian gabah sebesar 11 ton.

\section{Harga Beras}

Penelitian ini melihat harga beras di tingkat huller, pedagang besar, pedagang kecil dan konsumen. Beras dijual dengan merek yang beranekaragam dan setiap merek memiliki harga yang berbeda. Ditemukan perbedaan harga pada 24 responden pada penelitian ini.

\section{Harga beras di tingkat pedagang besar}

Pedagang besar merupakan seseorang yang menjual produk dalam jumlah besar. Harga yang berlaku di tingkat pedagang besar biasanya lebih murah dibandingkan harga di tingkat pedagang pengecer. Harga beras di tingkat pedagang besar dapat dilihat pada Tabel 3. Tabel 3 menunjukkan bahwa terdapat keragaman harga pada beberapa merek beras yang dijual oleh pedagang besar. Merek beras dengan harga tertinggi yaitu beras merek SJ, sedangkan merek beras dengan harga terendah yaitu beras merek RD. Diperoleh harga rata-rata semua merek beras sebesar Rp 11.842/kg.

Tabel 3. Harga beras di tingkat pedagang besar pada Februari 2018 di Bandar Lampung

\begin{tabular}{|c|c|c|c|c|}
\hline No & Merek & $\begin{array}{c}\text { Toko } \\
\text { Anugrah } \\
(\mathrm{Rp} / \mathrm{kg})\end{array}$ & $\begin{array}{c}\text { Toko } \\
\text { Putra } \\
\text { (Rp/kg) }\end{array}$ & $\begin{array}{c}\text { Rata-rata } \\
\text { (Rp/kg) }\end{array}$ \\
\hline 1. & SJ & 12.900 & 13.000 & 12.950 \\
\hline 2. & Dua Koki & 11.700 & 11,500 & 11.600 \\
\hline 3. & RD & 11.400 & 11,500 & 11.450 \\
\hline 4. & Merpati & 12.200 & 11.400 & 11,800 \\
\hline 5. & Mawar & 11.700 & 11.400 & 11.550 \\
\hline 6. & Mutiara & 11.400 & 12.000 & 11.700 \\
\hline \multicolumn{2}{|c|}{ Rata-rata } & 11.883 & 11.800 & 11.842 \\
\hline
\end{tabular}


Tabel 4. Harga beras premium di tingkat pengecer pada Februari 2018 di Bandar Lampung

\begin{tabular}{|c|c|c|c|c|}
\hline Merek & $\begin{array}{c}\text { Toko } \\
\text { Rozie } \\
\text { (Rp/kg) }\end{array}$ & $\begin{array}{c}\text { Toko } \\
\text { Abadi } \\
\text { (Rp/kg) }\end{array}$ & $\begin{array}{c}\text { Toko } \\
\text { Budi } \\
\text { (Rp/kg) }\end{array}$ & $\begin{array}{c}\text { Toko } \\
\text { Anto } \\
(\mathrm{Rp} / \mathrm{kg}) \\
\end{array}$ \\
\hline SJ & 14.000 & 14.000 & 13.500 & 14.000 \\
\hline Dua Koki & 13.500 & 13.700 & 13.000 & 13.500 \\
\hline $\mathrm{RD}$ & 11.500 & 11.700 & 11.800 & 11.500 \\
\hline Merpati & 12.500 & 12.600 & - & \\
\hline Mawar & 12.500 & 12.500 & - & 12.500 \\
\hline Mutiara & 13.000 & - & - & 13.000 \\
\hline Ramos & - & - & 11.800 & - \\
\hline $\begin{array}{l}\text { Cendrawa } \\
\text { sih }\end{array}$ & - & - & 11.000 & - \\
\hline Rata-rata & 12.833 & 12.900 & 12.220 & 12.900 \\
\hline
\end{tabular}

\section{Harga beras di tingkat pedagang pengecer}

Pedagang pengecer adalah pedagang yang menjual suatu produk atau komoditas secara langsung ke konsumen dalam jumlah yang sedikit. Harga beras premium di tingkat pedagang pengecer dapat dilihat pada Tabel 4. Tabel 4 menunjukkan bahwa terdapat keragaman harga pada beberapa merek beras yang beredar dipasaran. Merek beras dengan harga tertinggi yaitu beras merek SJ, sedangkan merek beras dengan harga terendah yaitu beras merek Cendrawasih. Wilayah penjualan ternyata juga mempengaruhi terjadinya perbedaan harga. Harga rata-rata tertinggi yaitu du toko anto sebesar $\mathrm{Rp} 12.900 / \mathrm{kg}$.

\section{Harga beras di tingkat konsumen}

Konsumen merupakan seseorang yang menggunakan atau membeli suatu produk. Setiap konsumen memiliki jumlah konsumsi beras yang berbeda yang dipengaruhi oleh jumlah anggota keluarga dan tidak ingin menyimpan berasnya terlalu lama. Harga beras di tingkat konsumen dapat dilihat pada Tabel 5.

Tabel 5 menunjukkan harga tertinggi beras yang dibeli oleh konsumen adalah beras dengan merek dua Koki yang berasal dari pasar Way Halim, sedangkan harga terendah yaitu beras dengan merek Cendrawasih yang berasal dari pasar Way Halim. Terdapat perbedaan harga beras merek yang sama pada pasar yang berbeda yaitu merek dua koki yang dijual pada pasar Rajabasa dan Way Halim, hal ini disebabkan oleh beberapa faktor seperti asal beras dan besarnya biaya transportasi yang dikeluarkan oleh pedagang.
Tabel 5. Harga beras di tingkat konsumen pada Februari 2018 di Bandar Lampung

\begin{tabular}{|c|c|c|c|c|}
\hline Merek & $\begin{array}{c}\text { Pasar } \\
\text { Rajabasa } \\
(\mathrm{Rp} / \mathrm{kg})\end{array}$ & $\begin{array}{c}\text { Pasar Way } \\
\text { Halim } \\
\text { (Rp/kg) }\end{array}$ & $\begin{array}{c}\text { Pasar } \\
\text { Tugu } \\
\text { (Rp/kg) }\end{array}$ & $\begin{array}{c}\text { Pasar } \\
\text { Way } \\
\text { Kandis } \\
\text { (Rp/kg) }\end{array}$ \\
\hline SJ & 13.500 & - & 13.500 & 13.500 \\
\hline 2 Koki & 13.000 & 14.000 & - & - \\
\hline $\begin{array}{l}\text { Cendra } \\
\text { wasih }\end{array}$ & - & 11.100 & - & - \\
\hline Ramos & - & & 11.800 & - \\
\hline $\mathrm{RD}$ & 11.800 & 11.800 & 11.800 & - \\
\hline $\begin{array}{c}\text { Rata- } \\
\text { rata }\end{array}$ & 12.767 & 12.300 & 12.367 & 13.500 \\
\hline
\end{tabular}

\section{Implementasi Peraturan Menteri Perdagangan Nomor 57 Tahun 2017 di Bandar Lampung}

Meter dan Horn mendefenisikan implementasi kebijakan sebagai tindakan yang dilakukan oleh publik maupun swasta yang ditujukan untuk mencapai tujuan yang telah ditetapkan dalam keputusan kebijakan (Safawi 2012). Peraturan menteri perdagangan nomor 57 tahun 2017 adalah peraturan yang dikeluarkan oleh menteri perdagangan yang berisi harga eceran tertinggi komoditas beras. Kelas mutu medium seharga Rp $9.450 / \mathrm{kg}$ dan kelas mutu premium seharga $\mathrm{Rp}$ $12.800 / \mathrm{kg}$. Penelitian ini memusatkan perhatian pada beras dengan kelas mutu premium dan diperoleh bahwa masih banyak beras yang dijual di atas harga eceran tertinggi yang telah ditetapkan. Harga beras eceran dapat dilihat pada Tabel 6 .

Tabel 6 menunjukkan terdapat tiga merek beras yang rata-rata harga jualnya di atas harga eceran tertinggi yang ditetapkan yaitu Rp 12.800/kg beras dengan merek SJ, Dua Koki dan Mutiara, sementara terdapat lima merek beras yang rata-rata harga jualnya di bawah harga eceran tertinggi yang sudah ditetapkan yaitu beras dengan merek RD, Mawar, Merpati, Ramos dan Cendrawasih.

Tabel 6 juga menunjukkan bahwa hanya terdapat satu pedagang pengecer yang rata-rata harga berasnya di bawah harga eceran tertinggi, sedangkan sisanya tiga pedagang pengecer menjual berasnya diatas harga eceran yang ditetapkan. Jumlah pedagang yang menjual diatas harga eceran tertinggi lebih banyak dibandingkan yang menjual dibawah atau setara harga eceran tertinggi maka dapat dikatakan bahwa implementasi peraturan menteri perdagangan nomor 57 tahun 2017 ini tidak berhasil. 
Tabel 6. Harga beras eceran pada Februari 2018 di Bandar Lampung

\begin{tabular}{lllccccc}
\hline No & \multicolumn{1}{c}{ Merek } & Kelas Mutu & $\begin{array}{c}\text { Toko Rozie } \\
(\mathrm{Rp} / \mathrm{kg})\end{array}$ & $\begin{array}{c}\text { Toko } \\
\text { Abadi } \\
(\mathrm{Rp} / \mathrm{kg})\end{array}$ & $\begin{array}{c}\text { Toko } \\
\text { Budi } \\
(\mathrm{Rp} / \mathrm{kg})\end{array}$ & $\begin{array}{c}\text { Toko } \\
\text { Anto } \\
(\mathrm{Rp} / \mathrm{kg})\end{array}$ & $\begin{array}{c}\text { Rata-rata } \\
(\mathrm{Rp} / \mathrm{kg})\end{array}$ \\
\hline 1. & SJ & Premium & 14.000 & 14.000 & 13.500 & 14.000 & 13.875 \\
2. & Dua Koki & Premium & 13.500 & 13.700 & 13.000 & 13.500 & 13.425 \\
3. & RD & Premium & 11.500 & 11.700 & 11.800 & 11.500 & 11.625 \\
4. & Merpati & Premium & 12.500 & 12.600 & - & & 12.550 \\
5. & Mawar & Premium & 12.500 & 12.500 & - & 12.500 & 12.500 \\
6. & Mutiara & Premium & 13.000 & - & - & 13.000 & 13.000 \\
7. & Ramos & Premium & - & - & 11.800 & - & 11.800 \\
8. & Cendrawasih & Premium & - & - & 11.000 & - & 11.000 \\
\hline \multicolumn{2}{r}{ Rata-rata } & & 12.833 & 12.900 & 12.220 & 12.900 & 12.472 \\
\hline
\end{tabular}

\section{Faktor pendukung dan faktor penghambat}

Faktor pendukung dan faktor penghambat Implementasi Peraturan Menteri Perdagangan Nomor 57 Tahun 2017 di Bandar Lampung diketahui dengan menggunakan pendekatan teori yang dikeluarkan oleh Ripley dan Franklin. Faktor pendukung yaitu adanya Standard Operating Procedures (SOP) peraturan yang dibuat, adanya badan pengawas yang dibentuk untuk mengawasi jalannya peraturan yaitu satuan tugas pangan, sedangkan faktor penghambat yaitu :

a. Tingkat kepatuhan terhadap ketentuan yang berlaku

Tingkat kepatuhan pedagang pengecer pada peraturan menteri perdagangan ini diukur melalui kepatuhan pedagang pengecer terhadap peraturan. Ditemukan 3 dari 4 pedagang yang tidak mematuhi harga eceram tertingi yang. Hal ini menunjukkan bahwa pedagang pengecer tidak patuh terhadap peraturan yang dikeluarkan, sehingga dapat disimpulkan rendahnya tingkat kepatuhan sebagai penghambat jalannya implementasi peraturan ini.

b. Lancarnya pelaksanaan rutinitas fungsi

Lancarnya pelaksanaan rutinitas fungsi dapat dilihat melalui kendala dari penerapan peraturan ini seperti :

(1) Kurangnya informasi yang diterima pedagang

Pada penelitian ini ditemukan 95 persen responden belum mengetahui adanya peraturan ini. Hal ini disebabkan oleh beberapa hal, diantaranya responden yang kurang memperbaharui informasi yang dimiliki mengenai harga pasar, pihak menteri perdagangan yang kurang dalam hal mensosialisasikan peraturan ini. Informasi yang kurang menjadi faktor penghambat implementasi peraturan ini.

(2) Isi peraturan yang tidak sesuai dengan keadaan dilapangan

Responden yang mengetahui adanya peraturan menteri perdagangan nomor 57 tahun 2017 sebanyak 5 persen, namun seluruh responden ini juga tidak menerapkan peraturan yang dikeluarkan dengan alasan harga eceran yang ditetapkan tidak sesuai dengan harga yang dibutuhkan, bahkan lebih rendah dari jumlah modal yang dikeluarkan oleh pedagang pengecer sehingga tidak memungkinkan untuk menerapkannya. Isi peraturan yang tidak sesuai menjadi faktor penghambat implementasi peraturan ini.

c. Terwujudnya kinerja dan dampak yang dikehendaki

Penetapan peraturan ini oleh menteri perdagangan tentunya memiliki tujuan, diantaranya mencapai kestabilan harga beras, mengurangi inflasi bahan pangan dan mengurangi kecurangan harga, namun dengan bukti dilapangan bahwa hanya satu responden yang menerapkan peraturan ini maka tujuan yang ingin dicapai oleh menteri perdagangan tidak dapat diwujudkan. Faktor penghambat yang cukup banyak menyebabkan tidak terwujudnya kinerja dan dampak yang dikehendaki dari pembuatan peraturan ini. 


\section{Rantai Pasok Beras}

\section{a. Struktur rantai pasok}

Menurut Punjawan (2005) rantai pasok merupakan jaringan perusahaan-perusahaan yang secara bersama-sama bekerja untuk menciptakan dan menghantarkan suatu produk ke tangan konsumen akhir. Rantai pasok terdiri dari beberapa unsur dan pihak yang terlibat baik secara langsung (primer) ataupun tidak langsung (sekunder). Pada rantai pasok beras ini terdapat anggota primer dan sekunder. Anggota primer terdiri dari petani, pemilik huller, pedagang besar, pedagang pengecer, dan konsumen, sedangkan anggota sekunder meliputi menteri perdagangan, Perusahaan umum badan urusan logistik (Perum Bulog) dan satuan tugas pangan.

\section{(1) Petani}

Sistem rantai pasok beras di Bandar Lampung dimulai dari hulu yaitu petani sebagai produsen bahan baku berupa gabah. Petani menjual gabah kepada huller atau mengolah gabah menjadi beras. Harga gabah dipengaruhi oleh kualitas gabah itu sendiri, situasi dan kondisi ketika pemanenan.

\section{(2) Huller}

Kegiatan yang dilakukan pemilik huller adalah membeli atau mengumpulkan gabah dari para petani disekitar lingkungannya kemudian mengubahnya menjadi beras.

\section{(3) Pedagang Besar}

Kegiatan yang dilakukan pedagang besar adalah membeli beras dalam jumlah besar dari huller, kemudian memasarkan kembali beras tersebut kepada para pedagang pengecer. Pedagang besar menjual beras pada pedagang pengecer baik pembeli tetap maupun pembeli baru. Pedagang besar akan mengirimkan beras sesuai pesanan kepada para pengecer. Rata-rata harga berlaku di tingkat pedagang besar sebesar $\mathrm{Rp}$ $11.842 / \mathrm{kg}$. Jumlah rata-rata pembelian beras oleh huller dari petani sebesar 11,16 ton per permbelian, sedangkan jumlah rata-rata penjualan beras oleh pedagang besar pada pedagang pengecer sebesar 1,67 ton perhari.

\section{(4) Pengecer}

Pedagang pengecer adalah pedagang yang menjual suatu komoditas langsung kepada konsumen dalam jumlah kecil. Dalam kegiatan ini pedagang pengecer memasarkan barang dagangannya dipasar-pasar.

\section{(5) Konsumen}

Konsumen beras membeli beras dalam jumlah sedikit dengan pertimbangan jumlah keluarga yang sedikit atau tidak ingin berasnya disimpan dalam jangka waktu yang lama. Konsumen membeli beras dalam jangka waktu perminggu atau perbulan.

\section{(6) Satuan Tugas Pangan}

Satuan Tugas (Satuan tugas) Pangan dibentuk pada Mei 2017. Satuan tugas Pangan Pusat dipimpin Kadivhumas Polri Irjen Pol Setyo Wasisto yang akan dibantu dengan sejumlah pejabat kementerian yakni Kementerian Dalam Negeri, Kementerian Pertanian, Kementerian Perdagangan, Perum Bulog dan Komisi Pengawas Persaingan Usaha (KPPU). Satuan tugas pangan Provinsi diketuai oleh Kapolda dan dibantu oleh beberapa pihak yaitu Perum Bulog, Dinas Ketahanan Pangan, Dinas Perdagangan, Dinas Perkebunan dan Bank Indonesia. Satuan tugas pangan berperan dalam menjaga kestabilan harga pangan, memastikan mutu pangan baik dan memastikan pendistirbusian pangan berjlan dengan baik.

Pada penelitian ini diketahui bahwa satuan tugas pangan melakukan pengecekan ke lapangan apabila menerima laporan bahwa terjadi gejolak harga di pasar. Pihak yang melakukan pengecekan terdiri dari anggota Satuan tugas Pangan, anggota Polda dan anggota Bank Indonesia. Apabila ditemukan pedagang beras yang menjual berasnya di atas harga eceran tertinggi yang ditetapkan satuan tugas pangan akan memberikan informasi kembali seputar harga eceran yang seharusnya dipatuhi. Satuan tugas pangan tidak berwenang memberikan sanksi karena pihak yang berwenang adalah Dinas Perdagangan. Satuan tugas pangan memiliki enumerator yaitu seseorang yang bertugas setiap harinya mengecek harga-harga pangan secara langsung ke pasar. Ketika 
harga pangan naik di lapangan maka satuan tugas pangan beserta pihak yang terlibat akan mengadakan rapat untuk menentukan kebijakan yang akan diambil.

\section{b. Pola Aliran dalam Rantai Pasok}

Dalam suatu rantai pasok terdapat tiga macam aliran yang harus dikelola yaitu, aliran barang yang mengalir dari hulu ke hilir, aliran finansial yang mengalir dari hilir ke hulu dan aliran informasi yang mengalir dalu hulu ke hilir ataupun sebaliknya.

\section{Aliran material}

Arus aliran material merupakan arus aliran barang yang terbentuk saat kegiatan rantai pasok berlangsung. Aliran material rantai pasok beras pada penelitian ini dapat dilihat pada Gambar 1. Gambar 1 menunjukkan bahwa aliran material yang terjadi dari petani ke huller berupa gabah. Rata-rata jumlah gabah yang dijual oleh petani sebesar 14 ton permusim panen, dari huller ke pedagang besar berupa beras dengan ratarata kapasitas giling sebesar 3,5 ton perhari, dari pedagang besar ke pedagang pengecer berupa beras dengan rata-rata jumlah penjualan beras sebesar 10 ton perhari dan dari pedagang pengecer ke konsumen berupa beras dengan rata-rata jumlah penjualan beras sebesar $106 \mathrm{~kg}$ perhari.

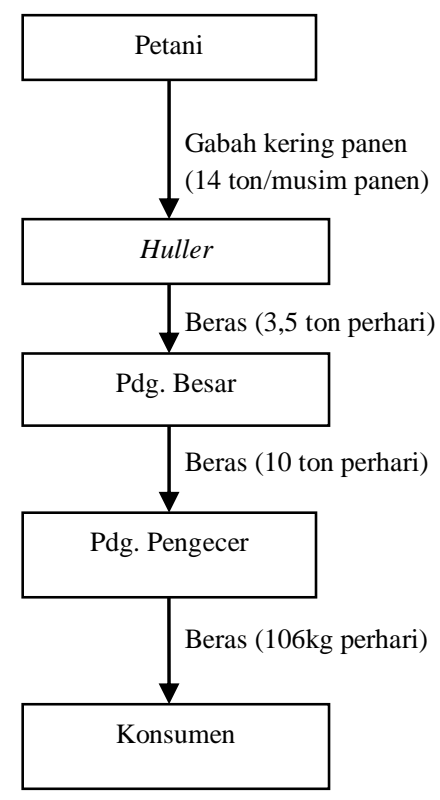

Gambar 1. Aliran material rantai pasok beras di Bandar Lampung

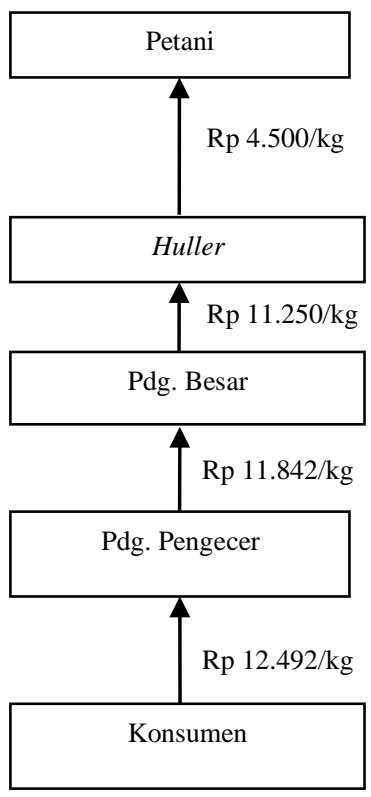

Gambar 2. Aliran finansial rantai pasok beras di Bandar Lampung

\section{Aliran finansial}

Arus aliran finansial merupakan arus aliran uang yang terbentuk saat kegiatan rantai pasok berlangsung. Masing-masing mata rantai yang terhubung terjadi pertukaran antara barang dengan jumlah tertentu dan uang dengan harga tertentu, sebagai balas jasa atas biaya produksi barang ditambah dengan laba. Aliran finasial rantai pasok beras dapat dilihat pada Gambar 2. Gambar 2 menunjukkan bahwa aliran finansial mengalir dari hilir ke hulu. Rata-rata jumlah uang yang mengalir dari konsumen ke pedagang pengecer sebesar Rp 12.492/kg, dari pedagang pengecer ke pedagang besar sebesar sebesar Rp 11.842/kg, dari pedagang besar ke huller sebesar Rp 11.250/kg dan dari huller ke petani sebesar Rp 4.500/kg.

\section{Aliran informasi}

Arus aliran informasi merupakan arus aliran informasi seputar kegiatan jual beli beras yang terbentuk saat kegiatan rantai pasok berlangsung. Aliran informasi mengalir secara timbal balik antar unsur rantai pasok. Masing-masing mata rantai yang terhubung terjadi pertukaran informasi yang berguna bagi masing-masing pihak. Aliran informasi rantai pasok beras dapat dilihat pada Gambar 3. 


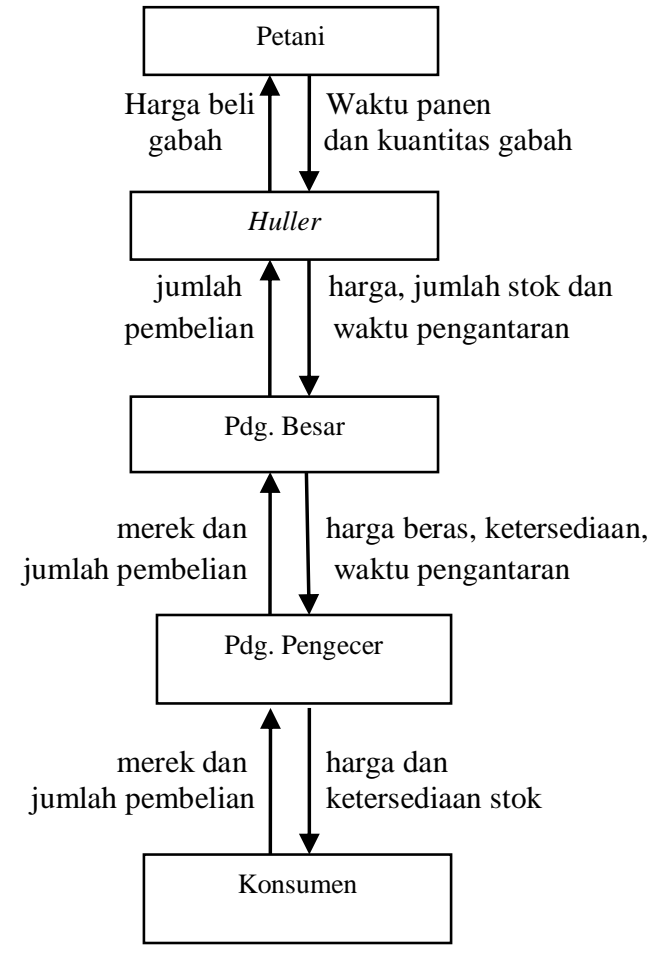

Gambar 3. Aliran infromasi rantai pasok beras

\section{KESIMPULAN}

Implementasi peraturan menteri perdagangan nomor 57 tahun 2017 di Bandar Lampung tidak efektif, hal ini dibuktikan hanya sebanyak 25 persen pedagang yang menerapkan peraturan harga eceran tertinggi yang ditetapkan. Faktor pendukung implementasi peraturan menteri perdagangan nomor 57 tahun 2017 yaitu adanya Standard Operating Procedures (SOP) peraturan yang dibuat, adanya badan pengawas yang dibentuk untuk mengawasi jalannya peraturan yaitu satuan tugas pangan. Faktor penghambat yaitu satuan tugas pangan yang dibentuk tidak berjalan sebagaimana mestinya, tingkat kepatuhan responden terhadap ketentuan yang berlaku sangat rendah sehingga tidak mengikuti peraturan yang telah ditetapkan, kurangnya sosialisasi dari pihak menteri perdagangan, isi peraturan yang tidak sesuai dengan keadaan dilapangan dan kurangnya informasi yang diterima oleh responden akibat kurangnya keingintahuan responden.

\section{DAFTAR PUSTAKA}

BPS [Badan Pusat Statistik Provinsi Lampung]. 2016. Bandar Lampung dalam angka. Bandar Lampung.

BPS [Badan Pusat Statistik Provinsi Lampung].. 2017. Bandar Lampung dalam angka. Bandar Lampung.

Fatih A. 2010. Implementasi Kebijakan Dan Pemberdayaan Masyarakat. Unpad Press. Bandung.

Kementerian Pertanian RI. 2016. Konsumsi ratarata per kapita setahun beberapa bahan makanan di Indonesia. Susenas 2012-2016. http://www.pertanian.go.id/Indikator/tabe-15 b-konsumsi-rata.pdf. [10 Desember 2017].

Kulsum U, Arifin B, dan Abidin Z. 2015. Determinan keputusan petani terhadap konversi lahan sawah menjadi permukiman. JIIA, 3 (2) : 187-194. http://jurnal.fp.unila .ac.id/index.php/JIIA/issue/view/102 . [10 Desember 2017].

Nopralita, Abidin Z dan Affandi MI. 2017. Dampak El Nino terhadap pendapatan rumah tangga petani gabah di Kecamatan Punggur, Kabupaten Lampung Tengah. JIIA, 5(2) : 179183. http://jurnal.fp.unila.ac.id/index.php/JI IA/issue/view/154 [10 Desember 2017]

Pujawan IN. 2005. Supply Chain Management. Guna Widya. Surabaya

Safawi I, Sujianto dan Rusly Z. 2010. Implementasi kebijakan retribusi parkir tepi jalan. Jurnal Kebijakan Publik, 3(2) : 890897. https://ejournal.unri.ac.id/index.php/JKP/ article/view/897/890. [10 Desember 2017].

Sugiyono. 2001. Metode Penelitian Kuantitatif, Kualitatif dan $R \& D$. Alfabeta. Bandung.

Surakhmad. 1994. Pengantar Penelitian Ilmiah Metode Teknik. Tarsito. Bandung.

Waluyo DE. 2002. Teori Ekonomi Makro. Gramedia. Jakarta. 